\title{
25 Research Soure \\ Protein-Based Biostimulants Enhanced Early Growth And Establishment Of Sugar Beet
}

Okanlawon Lekan Jolayemi ( $\nabla$ jolayemi.olalekan@slu.se )

Swedish University of Agricultural Sciences: Sveriges lantbruksuniversitet https://orcid.org/0000-00025643-4874

Ali Hafeez Malik

Nelson Seed Development AB

Tobias Ekblad

MariboHilleshög Research AB

Marie E. Olsson

Swedish University of Agricultural Sciences (SLU)

Eva Johansson

Swedish University of Agricultural Sciences (SLU)

\section{Manuscript}

Keywords: Hydrolyzed wheat gluten, potato protein film, potato protein powder, growth enhancement

Posted Date: February 8th, 2021

DOl: https://doi.org/10.21203/rs.3.rs-184009/v1

License: (c) (i) This work is licensed under a Creative Commons Attribution 4.0 International License.

Read Full License 


\section{Abstract}

\section{Purpose}

The effect of different concentrations, types and placements of protein-based biostimulants (PBs) on early growth and establishment of different varieties of sugar beet (Beta vulgaris L) was evaluated.

\section{Methods}

Three PBs with varying concentrations (0 to $10 \mathrm{~g} / \mathrm{kg}$ soil) and different placement methods in sandyclayey soil were tested for their enhancement effect on growth and establishment of three sugar beet varieties.

Results

All three PBs used in this study enhanced the growth of sugar beet by $59-127 \%$, compared to control. A content of 1 or $2 \mathrm{~g} / \mathrm{kg}$ soil showed significantly the highest effect on early plant growth, with an increase in plant height, plant canopy area and total biomass of sugar beet by $>100 \%,>165 \%$ and $195 \%$ respectively compared to the control. Generally, the three sugar beet varieties responded similarly to PB treatments and there was no difference in the effect of placement of the PBs on early sugar beet growth. However, the combination of the PB "potato protein film (PF)" with varieties I and III, showed a significantly positive effect on plant height and plant canopy area for treatment up to $5 \mathrm{~g} / \mathrm{kg}$ soil, compared to other PB-varieties combinations. A better enhancement effect was observed by the addition of PBs compared to nutrient solution, which implies that nutrients/amino acids was not the only reason for the positive effects of the PBs.

\section{Conclusion}

PBs, mixed with soil at low concentration, significantly enhanced early growth and establishment of sugar beet.

\section{Introduction}

Sugar beet (Beta vulgaris L) provides table sugar (sucrose) for the human population since the mid-19th century (Gurel et al. 2008). Currently, sugar beet accounts for about $37 \%$ of the world's total sugar production with the remaining 63\% coming from sugar cane (Biancardi et al. 2010). Sugar beet cultivation is concentrated in the temperate regions between $30^{\circ}$ and $60^{\circ} \mathrm{N}$ latitudes (Mahmoodi et al. 2008). A range of efforts has been undertaken to improve the vigor (seed germination and seedling establishment) of sugar beet seed and quality (sugar content) of the mature sugar beet (Hoffmann, 2017). The agronomic productivity of sugar beet depends significantly on the uniformity of seedling emergence in the field (Catusse et al. 2011; McGrath et al. 2000). 
Despite the efforts carried out, sugar beet germination and uniform establishment is still a challenge that needs to be improved. The problem of seedling establishment has been linked to the presence of natural germination-inhibitors present in the pericarp (Inoue and Yamamoto, 1974; Kulan et al. 2019). The pericarp also serves as a physical barrier for water and oxygen uptake, thereby retarding germination (Abts et al. 2013; Habib, 2010). Thus, sugar beet seeds require sophisticated seed enhancement techniques to optimize their germination capacity (Habib, 2010). The seed processing includes sorting or grading and polishing, together with seed enhancement processes (priming, pelleting and coating) (Taylor et al. 1997).

The effects of global climate change on the properties of the agricultural soils and interactions between climate and soil environments are known to have a significant impact on crop yield and quality (Ahuja et al. 2010; Bray et al. 2000; Holm et al. 2018; Koyro et al. 2012; Nicotra et al. 2010). Generally, crops with robust root systems and high nutrient-uptake efficiency are showing increased productivity, and thereby such crops have increased opportunities to combat the above-mentioned challenges (Halpern et al. 2015). Conventional and advanced molecular plant breeding are ways to develop resistant varieties to these stresses (pathogens, drought, saline, extreme temperatures as well as heavy metal toxicity stresses), however, they are time-consuming and capital intensive, respectively. Therefore, the use of biostimulants may be an interesting complimentary solution to the problems with conventional and molecular breeding techniques. A range of studies has indicated a positive effect of biostimulants on increasing root growth and ameliorating the impact of environmental stresses on plant growth and establishment (Canellas et al. 2002; 2015; Halpern et al. 2015; Khan et al. 2009; Zandonadi et al. 2007). Biostimulants are defined as "substances or materials, with the exception of nutrients and pesticides, which, when applied to plants, seeds, or growing substrates in specific formulations, have the capacity to modify physiological processes in plants in a way that provides potential benefits to growth, development, or stress response" (Wilson et al. 2018). The different categories of biostimulants include humic substances, seaweed extracts, plant-growth-promoting-bacteria and protein-based biostimulants (PBs) (Tanou et al. 2017). PBs, which are products of chemical, thermal and/or enzymatic hydrolysis of plant or animal-derived proteins, include protein hydrolysates (PH) and amino acids (AA) (Colla et al. 2014; Nardi et al. 2016). PHs contain mixtures of specific peptides and amino acids, which help to enhance plant growth and development (Cristiano et al. 2018; Nardi et al. 2016). Their applications are also increasing plant tolerance to both biotic and abiotic stresses (Ashraf and Foolad, 2007; Chen and Murata, 2008; Huang et al. 2011) and tolerance to heavy metal toxicity (Sharma and Dietz, 2006; Vranova et al. 2011). These specific peptides and amino acids vary widely in different $\mathrm{PH}$, ranging from $1-85 \%$ $(\mathrm{w} / \mathrm{w})$ and $2-18 \%(\mathrm{w} / \mathrm{w})$, respectively (Calvo et al. 2014). To the best of our knowledge, there is no scientific literature reporting the use of hydrolyzed wheat gluten (HWG) and potato protein (PP) as biostimulants to enhance growth and establishment of sugar beet. However, preliminary studies from our group have indicated some positive effects of HWG and PP on growth of sugar beet seedlings, while applied in the seed pellet (Johansson et al. 2017).

Therefore, the objectives of this study were to i) assess the early establishment and growth of sugar beet, if HWG and PP are used as a biostimulant, ii) to evaluate interactions between variety and PB treatments, 
and iii) to understand the interplay between soil, crop and biostimulant when it comes to sugar beet and protein-based biostimulant uses.

\section{Materials And Methods}

\section{Plant material and growth conditions}

Three commercial hybrid seeds of sugar beet varieties were used in this experiment, provided by Maribo Hilleshög Research AB, Landskrona, Sweden. The seeds were sown in $786 \mathrm{ml}$ plastic pots at the rate of two seeds per pot, which were thinned to one seedling per pot after germination. Each pot was watered daily with approximately $100 \mathrm{ml}$ per day. The experiment was set up in a climate chamber in the Biotron, SLU, Alnarp, for 4 weeks. Day length $(13 / 11 \mathrm{~h})$, average temperature $\left(10.0^{\circ} \mathrm{C}\right.$ and $3.0^{\circ} \mathrm{C}$ respectively), relative humidity $(60-70 \%)$ and light intensity $\left(0-1000 \mu \mathrm{mol} \mathrm{m}^{-2} \mathrm{~s}^{-1}\right)$ were all controlled in the climate chamber. The environmental parameters were chosen in a way to reflect the natural environment during the planting season of sugar beet, which is between March and April in South Sweden. After 4 weeks in the Biotron, the experiment was moved to the greenhouse for another 4 weeks. In the greenhouse, only relative humidity $(80-90 \%)$ and temperature $\left(12-15^{\circ} \mathrm{C}\right)$ were controlled, whereas day length and light intensity from outside the greenhouse were used.

Soil and biostimulant treatments

To evaluate growth responses to biostimulants, sugar beet plants were exposed to different levels of protein-based biostimulants in the soil. Two protein-based biostimulants (HWG and PP) were used in this experiment. Lyckeby, Sweden, kindly provided PP while HWG was purchased from A. Constantino \& Co. S.P.A., Italy. Chemical compositions of the two PBs (HWG and PP) are presented in Table 1. Sandy-clayey soil (50/50) from Bara Mineraler, Malmo Sweden, was used in this experiment. The choice of the soil was to allow for maximum root extraction for root biomass analysis and convenience of mixing HWG and PP evenly with soil. Each pot contained $500 \mathrm{~g}$ soil well-mixed with corresponding quantities of either HWG or PP at the rate of 1,2,5 and $10 \mathrm{~g} / \mathrm{kg}$ soil. The HWG or PP was either mixed with the soil or placed at about $2 \mathrm{~cm}$ below the seeds (Table 2).

Furthermore, friable solution-cast films of HWG and PP were produced to mimic granules to be added to soil. Ten percent solution-cast film of HWG and PP was produced by adding $50 \mathrm{~g}$ of HWG or PP powder over a $5 \mathrm{~mm}$ sieve, into $500 \mathrm{ml}$ of milli-Q water placed on a magnetic stirrer at a speed of $500 \mathrm{rpm}$ in order to dissolve the powder. A total of $50 \mathrm{ml}$ of the solution was then dispensed into petri-dishes $(100 \mathrm{~mm} \times 15$ $\mathrm{mm}$ ) and placed in a ventilated oven drier (model- Konsortiet Termaks) for $48 \mathrm{~h}$ at $45^{\circ} \mathrm{C}$, resulting in a dried friable cast-film. However, the HWG could not form friable films due to high plastic nature of gluten in the HWG, and therefore only PP film (PF) was evaluated in this experiment and added to soil at similar concentration as described above.

Experimental design and data collection 
The experiment was laid out in a completely randomized design with five replicates per treatment. Growth parameter data (days-to-emergence, plant height, plant canopy area and total biomass) were collected throughout the experiment. Days-to-emergence data was collected every day from the sowing date until the last seeds emerged from the soil. Days-to-emergence was calculated using the formula below:

\section{Days-to-emergence $=$}

Plant height was measured weekly with a $30-\mathrm{cm}$ ruler from the soil surface to the tip of the tallest leaf. Plant canopy area was measured every other week by taking aerial photographs of plants using an Android phone (Alcatel model- 5059D, 13 MP pixels) from a stable and uniform height (30 cm from tabletop). Each picture was analyzed using easy-leaf-area (ELA), which is an open source software (Easlon and Bloom, 2014).

At 8 weeks-after-planting (WAP), sugar beet seedlings were gently uproots and roots were thoroughly washed under gently running tap to remove soil particles. Shoot and root were separated to evaluate the fresh shoot and root biomass ( $\mathrm{g}$ fresh weight plant $\mathrm{t}^{-1}$ ). Fresh shoot and root weight was determined by placing the separated shoot and root on a calibrated digital weighing balance. Total biomass ( $\mathrm{g}$ fresh weight plant ${ }^{-1}$ ) was estimated by adding the values of fresh shoot weight and fresh root weight.

Additional experiment

A supplementary experiment was conducted to compare the best treatments from the above experiment (HWG, PF and PP) with nutrient solution in order to understand if the impact of PBs could be attributed to nutrients/amino acids from the PBs. The nutrient solution applied was generously provided by Maribo Hilleshög Research AB, Landskrona. The nutrient solutions contained macronutrients and micronutrients in concentrations suitable for greenhouse cultivation of sugar beet seedlings. The diluted solutions, as used in these experiments, contained $271 \mathrm{mg} \mathrm{N}, 56 \mathrm{mg} \mathrm{P}, 331 \mathrm{mg} \mathrm{K}, 70 \mathrm{mg} \mathrm{Mg}, 169 \mathrm{mg}$ Ca and $61 \mathrm{mg} \mathrm{S}$ per liter. In addition, they also contained trace amounts of $\mathrm{Fe}, \mathrm{Mn}, \mathrm{Cu}, \mathrm{Zn}, \mathrm{B}$ and Mo.. Nutrient-solution treatment was composed of sugar beet seeds planted in sandy soil without biostimulant, and applied at the rate $25 \mathrm{ml}$ per plant at 4 WAP, whereas the best HWG, PF and PP treatments were prepared similar to the method described in the above experiment. Data on growth parameters were collected at 8 WAP and analyzed. Bar charts were made using MS Excel spreadsheet and each bar is a mean of 4 replicates and separated using standard error of mean.

Statistical analysis

Analysis of variance (ANOVA) was performed on all growth parameters data (days-to-emergence, plant height, plant canopy area and total biomass) to detect significant differences in their mean square values using the "anova(mod)" function in Library(car) package of R studio. Tukey's pairwise comparison posthoc test (at $p<0.05$ ) was used to evaluate significant differences of the growth parameters. Principal component analysis was done on all growth parameters using MINITAB 18, in order evaluate the 
relationship between different experiment factors including varieties, and types and amount of biostimulants.

\section{Results}

Effect of variety, type, amount and placement of biostimulant on the development of sugar beet

The ANOVA results clearly showed that days-to-emergence, plant height, plant canopy area and total biomass of sugar beet were significantly influenced by differences in variety, type of biostimulant (except total biomass) and amount of biostimulants, as well as by the interactions of type and amount of biostimulants (Table 3). Placement of the biostimulant did not affect any of the evaluated plant characters (Table 3).

Variety III emerged significantly later, but resulted in significantly higher biomass as compared to the other two varieties, while variety I resulted in significantly higher plants than variety II (Table 4). No significant differences were seen in plant canopy area among the evaluated varieties of sugar beet (Table 4).

Sugar beet seedlings under PF and PP treatments emerged significantly earlier as compared to sugar beet seedlings under HWG treatment. The PF treatment also enhanced plant height of sugar beet seedlings as compared to HWG and PP treatments, and increased plant canopy area as compared to PP treatment (Table 4). No significant differences were seen in total biomass of sugar beet plants for the different biostimulant types applied (Table 4).

The emergence of sugar beet seedlings was progressively delayed with increasing amounts of biostimulant from $0-10 \mathrm{~g} / \mathrm{kg}$ soil (Table 4). Significantly higher plants and larger plant canopy area were obtained with the use of $1-2 \mathrm{~g} / \mathrm{kg}$ biostimulant in the soil, than with other contents of biostimulants, while total biomass was higher with $2 \mathrm{~g} / \mathrm{kg}$ biostimulant than with other content of additions (Table 4).

Interaction effects of type and amount of biostimulants on early establishment and growth of sugar beet

Principal Component Analysis (PCA) (Fig 1) revealed that variables clustered into three main groups, based on the amount of biostimulant treatment sorted by variety and type of biostimulant (Fig 1a and $b$ respectively). Control samples with no biostimulant treatment $(0 \mathrm{~g} / \mathrm{kg}$, blue circle) clustered on the lower left side of the PCA, with negative values for both PC1 and PC2 (Fig 1a and b). These results indicated comparatively low values for all measured growth parameters and thus weak plant development, with the exception that the low days-to-emergence values must be seen as positive. Generally, samples under 1 and $2 \mathrm{~g} / \mathrm{kg}$ (red box and green diamond) biostimulant treatments clustered on the positive axis of the first principal component (PC1, x-axis) (Fig 1a and b), indicating the comparatively highest plant height, plant canopy area and total biomass (compare Fig $1 \mathrm{a}$ and b with 1c). Most of the 5 and $10 \mathrm{~g} / \mathrm{kg}$ (purple and grey triangle) biostimulant samples clustered on the negative PC1 axis, which indicated reduced growth of sugar beet (Fig $1 \mathrm{a}$ and $\mathrm{b}$ ). The PCA also clearly revealed the interaction of variety and biostimulant 
type with amount of biostimulant on the growth parameters of sugar beet (Fig 1). All three varieties responded in similar manner to the amount of biostimulant in terms of plant height, plant canopy area and total biomass (Fig 1a). However, a positive effect of high amount ( 5 and $10 \mathrm{~g} / \mathrm{kg}$ ) of biostimulant on days-to-emergence was more obvious for varieties I and II compared to variety III (Fig 1a). Furthermore, the high amount ( 5 and $10 \mathrm{~g} / \mathrm{kg}$ ) of biostimulants resulted to a higher extent in prolonged days-toemergence when HWG was used than when PF and PP was applied (compare Fig $1 \mathrm{~b}$ and $\mathrm{c}$ ). This indicated that high amount of HWG added was more negative than PP and PF for the emergence of sugar beet. However, no such clear patterns were observed for the different varieties or types of biostimulants at lower amounts (1 and $2 \mathrm{~g} / \mathrm{kg}$ ) (Fig $1 \mathrm{a}$ and b).

Effect of HWG, PF, PP in comparison with nutrient solution on growth parameters of sugar beet A significantly $(p<0.001)$ higher plant height, plant canopy area and total biomass was observed for sugar beet under PB treatments in comparison to when nutrient solution was added (Fig 2).

\section{Discussion}

In this study, we showed clearly that protein-based biostimulants- PBs (HWG, PF and PP) improved early growth and establishment of sugar beet. The enhancement effect of these PBs on all growth parameters (plant height, plant canopy area and total biomass) of sugar beet except days-to-emergence was observed at low concentration (1-2 g/kg). This growth enhancement effect was also observed irrespective of mode of application (bottom-dressing and soil mixture) of PBs in the soil. We have been able to prove that both HWG and PP, which are side-stream agro-industrial products from wheat and potato respectively, can be used as biostimulants like other PBs from animal or plant sources (Colla et al. 2015; Cristiano et al. 2018; Gaidau et al. 2013). Growth-enhancing effects reported in this study, similar to the ones in previous studies evaluating other PBs, have been linked to their hormone-like activities (Colla et al. 2014). An explanation for such activities by PBs are the fact that they are made of up mixtures of low molecular weight forms of organic $\mathrm{N}$ (amino acids and oligopeptides) which are precursors for the biosynthesis of plant hormones that stimulate plant growth and development (Colla et al. 2014; Ertani et al. 2009). These amino acids and oligopeptides mixtures are easily taken up by plant roots and utilized for plant growth and development (Greenfield et al. 2020). Apart from growth stimulation, PBs have been reported to stimulate metabolic processes that increase the resistance or tolerance of plant to abiotic stresses (Colla et al. 2017; Ertani et al. 2013) as well as enhance plant photosynthetic capacities, which are important physiological processes (Fascella et al. 2018; Gurav and Jadhav, 2013; Massa et al. 2016; Paul et al. 2019). Thus, the enhancement effect we observed in sugar beet might be the result of the plant's ability to take up low molecular weight organic $\mathrm{N}$ for growth and development from the PBs added.

Our result on the effect of HWG, PF and PP on sugar beet biomass is comparable or in some cases even better compared to previous reports on the effects on biostimulants on crop growth. The increase in fresh or dry biomass of different crops compared to control treatment varied from 17->190\% (Table 5), while 
the increase of sugar beet biomass as compared to the control varied between 49 and $>190 \%$ in the present study (Table 4), with the highest value of $>1000 \%$ in the additional experiment (Fig 2c).

HWG is derived from chemical, thermal, or enzymatic hydrolysis or a combination of hydrolysis processes of wheat gluten resulting in $3.7 \%$ amino $\mathrm{N}$ and $13.1 \%$ total $\mathrm{N}$ (Burnett et al. 2018). Whereas, PP is derived from the harsh acidic and thermal precipitation of potato fruit juice, and PP contain patatin as its major protein fraction (40\%) (Capezza, 2020; Muneer, 2018) (Table 1). The processes of producing both HWG and PP result in mixtures of amino acids and oligopeptides like in most other PBs (Colla et al. 2015; Greenfield et al. 2020). PBs, including HWG and PP are generally cheap and readily available and they have been used as protein supplements in animal feed (Capezza, 2020). Therefore, we consider both HWG and PP as relatively sustainable and eco-friendly alternatives to the use of chemical fertilizers, pesticides and petroleum-based pellets in crop production. Thus, PBs from HWG and PP could be seen as good sources for crop enhancements.

Our results are in accordance with the findings of Cristiano et al. (2018) and Qurartieri et al. (2002), evaluating the effect of PBs on the growth and physiology of snapdragon and kiwi plants respectively. We observed higher plant height of sugar beet when treated with low concentration of PBs. Cristiano et al. (2018) and Qurartieri et al. (2002) also reported that PBs enhanced both above- and below-ground parts of these plants at low dosage. In similar manner, Colla et al. (2014) reported increase in coleoptile length (in corn) and shoot length (in dwarf pea) under PBs depending on concentration applied. In addition, Amirkhani et al. (2016) reported increase in plant height of broccoli raised from seeds coated with soyprotein-biostimulant. Similarly, Ertani et al. (2009) also observed increase in plant height of maize after treating with two PBs (one from Alfalfa and the other meat flour). Furthermore, Parrado et al. (2008) showed that PBs from carob germ enhanced plant height of tomato. The effect of the different PBs on plant height have in general, been linked primarily to their phytohormonal actions (Colla et al. 2014; Ertani et al. 2009; Parrado et al. 2008).

Our findings on enhanced-plant canopy area of sugar beet under low concentration of HWG, PF and PP (Fig 1b) is supported by the reports from different authors (Cristiano et al. 2018; Ertani et al. 2009; Paul et al. 2019). They showed that PBs from different sources (plant and animal) resulted in increased plant canopy of snapdragon, maize and tomato respectively. Plant canopy area of Lantana spp was also found to increase under PB of biowaste materials (Fascella et al. 2018).

In our study, plant biomass of sugar beet was greatly influenced by HWG, PF and PP treatments. Similarly, biomass of broccoli, corn and lettuce was increased under plant derived-PH treatments (Amirkhani et al. 2016; Ertani et al. 2013; Lucini et al. 2015). In another study, Di-Mola et al. (2019) also reported increase in biomass of rocket vegetable under legume-based $\mathrm{PH}$ and tropical plant extract treatments. Gurav and Jadhav, (2013) also found out that PH derived from feather waste enhanced banana biomass. In a study to test the effect PB from two urban biowaste materials, Massa et al. (2016) also reported increase in growth of Hibiscus plant including total biomass. 
The growth-enhancement effects of protein-based biostimulants on different crops have been reviewed (Colla et al. 2015; Colla et al. 2017; Van-Oosten et al. 2017). Generally, biostimulants have been reported to enhance nutrient uptake, metabolism and increase crop resistance to abiotic stresses (Cavani et al. 2017). There are also reports of decrease in salt accumulation as well as regulation of hormonal and gene expression systems among other things, in tissues of crops treated with $\mathrm{PH}$ and AA, (Table 5).

HWG, PF and PP enhanced growth of sugar beet better compared to nutrient solution. This suggested that the effect of the PBs (HWG, PF and PP) may not be restricted to nutrient supply.

\section{Conclusion}

Our study is the first to report the biostimulating effect of HWG, PF and PP on early growth and establishment of sugar beet. HWG, PF and PP are interesting to be used as PBs as they are relatively cheap, abundant and readily available as side-streams of the starch and ethanol production from wheat and potatoes. This study therefore visualized opportunities for these side-streams, of HWG and PP (powder or casted film) to be utilized as biostimulants for improving crop growth and development when applied at low concentration in the soil. We suggest that HWG and PP could be applicable as biostimulants for a wide range of crops especially in nutrient-deficient soils.

\section{Abbreviations}

Protein-based biostimulant (PB), amino acids (AA), hydrolyzed wheat gluten (HWG), potato protein film (PF) and potato protein powder (PP)

\section{Declarations}

\section{Funding}

This research was funded by the strategic research area Trees and Crops for the Future (TC4F) and Partnership Alnarp, SLU

\section{Conflicts of Interest}

The authors declare that they have no known conflict of interests that could have influenced the work reported in this paper

\section{Availability of data and material}

Not applicable

\section{Code availability}

Not applicable 


\section{Authors' contributions}

Not mandatory

\section{Acknowledgement}

We wish to thank Trees and Crops for the Future (TC4F), a Strategic Research Area at SLU for its financial support to this study. Also we thank Partnership Alnarp, SLU for partly providing funds for this project. Maribo Hilleshög Research AB Sweden, is appreciated for partnering with the project and Lyckeby Sweden for kindly supplying potato protein.

\section{References}

Abts W, Vissers K, Vandenbussche B, De-Proft MP (2013) Study of ethylene kinetics during and after germination of sugar beet (Beta vulgaris L.) seeds and fruits. Seed Sci Res 23: 205-210

Ahuja I, deVos RCH, Bones AM, Hall, RD (2010) Plant molecular stress responses face climate change. Trends Plant Sci 15: 664-674. doi: 10.1016/j.tplants.2010.08.002

Al-Malieky HMH, Jerry AN (2019) Preparation Protein Hydrolysates from Fish by-product and Study Effected on Lettuce (Lactuca sativa L.) Growth, Yield, Quality and Enhanced Salt Tolerance. Basrah J Agric Sci 32: 246-255. https://doi.org/10.37077/25200860.2019.272

Amirkhani M, Netravali AN, Huang W (2016) Investigation of soy protein-based biostimulant seed coating for broccoli seedling and plant growth enhancement. Hortic Sci 51: 1121-1126. doi: 10.21273/HORTSCI10913-16

Ashraf M, Foolad MR (2007) Roles of glycine betaine and proline in improving plant abiotic stress resistance. Environ Exp Bot 59: 206-216

Baglieri A, Cadili V, Mozzetti MC, et al (2014) Fertilization of bean plants with tomato plants hydrolysates. Effect on biomass production, chlorophyll content and N assimilation. Sci Hortic 176: 194-199. https://doi.org/https://doi.org/10.1016/j.scienta.2014.07.002

Biancardi E, McGrath JM, Panella LW, Lewellen RT, Stevanato P (2010) Sugar beet. In Root and tuber crops (pp. 173-219) Springer

Bray EA, Bailey-Serres J, Weretilnyk E (2000) Responses to abiotic stresses. In: Buchanan BB, Gruissem W, Jones RL (eds) Biochemistry and molecular biology of plants. America Society of Plant Physiologists, Rockville, pp 1158-1203

Burnett C, Bergfeld WF, Belsito DV, et al (2018) Safety Assessment of Hydrolyzed Wheat Protein and Hydrolyzed Wheat Gluten as Used in Cosmetics. Int J Toxicol 37: 55s-66s.

https://doi.org/10.1177/1091581818776013

Page $10 / 20$ 
Calvo P, Nelson L, Kloepper JW (2014) Agricultural uses of plant biostimulants. Plant Soil, 383 (1-2): 3-41. https://doi.org/10.1007/s11104-014-2131-8

Cavani L, Margon A, Sciubba L, Ciavatta C, Marzadori C (2017) What we talk about when we talk about protein hydrolysate-based biostimulants. AIMS Agriculture and Food 2 (3): 221-232

Canellas LP, Olivares FL, Okorokaova-Façanha AL, Façanha AR (2002) Humic acids isolated from earthworm compost enhance root elongation, lateral root emergence, and plasma membrane $\mathrm{H}^{+}$-ATPase activity in maize roots. Plant Physiol 130: 1951-1957

Canellas LP, Olivaresa FL, Aguiara NO et al (2015) Humic and fulvic acids as biostimulants in horticulture. Sci Hortic 196: 15-27

Cardarelli M, Rouphael Y, Coppa E, Hoagland L, and Colla G (2020) Using Microgranular-Based Biostimulant in Vegetable Transplant Production to Enhance Growth and Nitrogen Uptake. Agronomy 10 (842): $1-12$

Capezza AJ (2020) Sustainable Biobased Protein Superabsorbents from Agricultural Co-Products. (PhD dissertation). KTH Royal Institute of Technology, Stockholm. Retrieved from http://urn.kb.se/resolve? urn=urn:nbn:se:kth:diva-281719

Caruso G, De-Pascale S, Cozzolino E, et al (2019) Yield and Nutritional Quality of Vesuvian Piennolo Tomato PDO as Affected by Farming System and Biostimulant Application. 9 (9): 505. https://www.mdpi.com/2073-4395/9/9/505

Catusse J, Meinhard J, Job C et al (2011) Proteomics reveals potential biomarkers of seed vigor in sugarbeet. Proteomics 11: 1569-1580. DOI 10.1002/pmic.201000586

Chen THH, Murata N (2008) Glycine betaine: an effective protectant against abiotic stress in plants. Trends Plant Sci 13: 499-505

Colla G, Rouphael Y, Canaguier R et al (2014) Biostimulant action of a plant-derived protein hydrolysate produced through enzymatic hydrolysis. Front Plant Sci 5 (448) doi: 10.3389/fpls.2014. 00448

Colla G, Nardi S, Cardarelli M, et al (2015) Protein hydrolysates as biostimulants in horticulture. Sci Hortic, 196: 28-38 https://doi.org/https://doi.org/10.1016/j.scienta.2015.08.037

Colla G, Hoagland L, Ruzzi M et al (2017) Biostimulant action of protein hydrolysates: unraveling their effects on plant physiology and microbiome. Front Plant Sci 8: 2202. http://dx.doi.org/10.3389/ fpls.2017.02202

Cristiano G, Pallozzi E, Conversa G, et al (2018) Effects of an Animal-Derived Biostimulant on the Growth and Physiological Parameters of Potted Snapdragon (Antirrhinum majus L.). Front Plant Sci 9: 861 doi: 10.3389/fpls.2018.00861 
Di Mola I, Ottaiano L, Cozzolino E, et al (2019) Plant-Based Biostimulants Influence the Agronomical, Physiological, and Qualitative Responses of Baby Rocket Leaves under Diverse Nitrogen Conditions. Plants 8 (11): 522. https://www.mdpi.com/2223-7747/8/11/522

Easlon HM, Bloom AJ (2014) Easy Leaf Area: Automated digital image analysis for rapid and accurate measurement of leaf area. Appl Plant Sci 2: 1400033. https://doi.org/10.3732/apps.1400033

Ertani A, Cavani L, Pizzeghello D et al (2009) Biostimulant activity of two protein hydrolysates on the growth and nitrogen metabolism in maize seedlings. J Plant Nutr Soil Sc 172: 237-244

Ertani A, Schiavon M, Muscolo A, Nardi S, (2013) Alfalfa plant-derived biostimulant stimulate short-term growth of salt stressed Zea mays L. plants. Plant Soil 364: 145-158. DOI 10.1007/s11104-012-1335-Z

Ertani A, Schiavon M, Nardi S (2017) Transcriptome-Wide Identification of Differentially Expressed Genes in Solanum lycopersicon L. in Response to an Alfalfa-Protein Hydrolysate Using Microarrays[Original Research] 8 (1159). https://doi.org/10.3389/fpls.2017.01159

Ertani A, Nardi S, Francioso O, et al (2019) Effects of two protein hydrolysates obtained from chickpea (Cicer arietinum L.) and Spirulina platensis on Zea mays (L.) Plants [Original Research] 10 (954). https://doi.org/10.3389/fpls.2019.00954

Fascella G, Montoneri E, Francavilla M (2018) Biowaste versus fossil sourced auxiliaries for plant cultivation: The Lantana case study. J Clean Prod 185: 322-330.

Gaidau C, Niculescu M, Stepan E, Epure DG, Gidea M (2013) New Mixes Based on Collagen Extracts with Bioactive Properties, for Treatment of Seeds in Sustainable Agriculture. Curr Pharm Biotechnol, 14 (9): 792-801. https://www.ingentaconnect.com/content/ben/cpb/2013/00000014/00000009/art00002

Genç E, Atıcı Ö (2019) Chicken feather protein hydrolysate as a biostimulant improves the growth of wheat seedlings by affecting biochemical and physiological parameters Turk J Bot, 43 (1): 67-79 . Retrieved from https://dergipark.org.tr/en/pub/tbtkbotany/issue/42507/512129

Greenfield LM, Hill PW, Paterson E, Baggs EM, Jones DL (2020) Do plants use root-derived proteases to promote the uptake of soil organic nitrogen? Plant Soil 456 (1): 355-367.

https://doi.org/10.1007/s11104-020-04719-6

Gurav RG, Jadhav JP (2013) A novel source of biofertilizer from feather biomass for banana cultivation. Environ Sci Pollut Res, 20 (7): 4532-4539. https://doi.org/10.1007/s11356-012-1405-z

Gurel E, Gurel S, Lemaux PG (2008) Biotechnology Applications for Sugar Beet. CRC Crit Rev Plant Sci, 27 (2): 108-140. doi:10.1080/07352680802202000

Habib M (2010) Sugarbeet (Beta vulgaris L.) seed pre-treatment with water and $\mathrm{HCl}$ to improve germination. Afr J Biotechnol 9: 1338-1342 
Halpern M, Bar-Tal A, Ofek M et al (2015) The use of biostimulants for enhancing nutrient uptake. D.L. Sparks (Ed.) Adv Agron 129: 141-174

Hoffmann CM. (2017) Changes in root morphology with yield level of sugar beet. Sugar IndustryZuckerindustrie, 142 (7): 420-425. <Go to ISI>://WOS:000405262300011

Holm L, Malik AH, Johansson E (2018) Optimizing yield and quality in malting barley by the governance of field cultivation conditions. J Cereal Sci 82: 230-242.

Huang TF, Jander G, de-Vos M (2011) Non-protein amino acids in plant defense against insect herbivores: Representative cases and opportunities for further functional analysis. Phytochem 72 (13): 1531-1537. https://doi.org/10.1016/j.phytochem.2011.03.019

Inoue K, Yamamoto R (1974) The growth inhibitors in sugar beet seed balls. I. Isolation of mono-sodium oxalate as a root growth inhibitor. Proc Crop Soc Japan 43 (3): 439-444

Johansson E, Newson WR, Fredlund K, Malik AH (2017) Proteinbaserad utsädespelletering - för ökad avkastning hos sockerbeta? Alnarp, Sveriges lantbruksuniversitet. LTV-fakultetens faktablad; 2017:8 (Factsheet)

Khan W, Rayirath UP, Subramanian S, (2009) Seaweed extracts as biostimulants of plant growth and development. J Plant Growth Regul 28: 386-399

Koyro HW, Ahmad P, Geissler N (2012) Abiotic stress responses in plants: an overview. In: Ahmad P, Prasad MNV (eds) Environmental adaptations and stress tolerance of plants in the era of climate change. Springer Science + business media, New York, pp 1-28

Kulan EG, Takil ED, Kaya MD (2019) A Simple Estimation of Seed Viability and Emergence Potential in Sugar Beet. Sugar Tech 21: 532-535. doi:10.1007/s12355-018-0666-3

Lucini L, Rouphael Y, Cardarelli M, Canaguier R, Kumar P, Colla G (2015) The effect of a plant-derived biostimulant on metabolic profiling and crop performance of lettuce grown under saline conditions. Sci Hortic, 182: 124-133. https://doi.org/10.1016/j.scienta.2014.11.022

Mahmoodi R, Maralian H, Aghabarati A (2008) Effects of limited irrigation on root yield and quality of sugar beet (Beta vulgaris L.). Afr J Biotechnol 7 (24): 4475-4478. http://www.academicjournals.org/AJB

Massa D, Prisa D, Montoneri E, et al (2016) Application of municipal biowaste derived products in Hibiscus cultivation: Effect on leaf gaseous exchange activity, and plant biomass accumulation and quality. Sci Hortic 205: 59-69. doi:https://doi.org/10.1016/j.scienta.2016.03.033

McGrath JM, Derrico CA, Morales M, et al (2000) Germination of sugar beet (Beta vulgaris L.) seed submerged in hydrogen peroxide and water as a means to discriminate cultivar and seedlot vigor. Seed Sci and Technol 28: 607-620 
Muneer F (2015) Biocomposites from natural polymers and fibers. Alnarp: (LTJ, LTV) > Department of Plant Breeding (from 130101), Sveriges lantbruksuniversitet. Introductory paper at the Faculty of Landscape Architecture, Horticulture and Crop Production Science [Report]

Nardi S, Pizzeghello D, Schiavon M, Ertani A (2016) Plant biostimulants: physiological responses induced by protein hydrolyzed-based products and humic substances in plant metabolism. Sci Agr 73 (1): 18-23. http://dx. doi.org/10.1590/0103-9016-2015-0006

Nicotra AB, Atkin OK, Bonser SP et al (2010) Plant phenotypic plasticity in a changing climate. Trends Plant Sci 15: 684- 692

Parrado J, Bautista J, Romero EJ, García-Martínez AM, Friaza V, Tejada M (2008) Production of a carob enzymatic extract: Potential use as a biofertilizer. Biores Techn 99 (7): 2312-2318. https://doi.org/https://doi.org/10.1016/j.biortech.2007.05.029

Paul K, Sorrentino M, Lucini L, et al (2019) Understanding the Biostimulant Action of Vegetal-Derived Protein Hydrolysates by High-Throughput Plant Phenotyping and Metabolomics: A Case Study on Tomato [Original Research]. 10 (47). https://doi.org/10.3389/fpls.2019.00047

Qurartieri M, Lucchi A, Cavani L (2002) Effects of the rate of protein hydrolysis and spray concentration on growth of potted kiwifruit (Actinidia deliciosa) plants. DOI: 10.17660/ActaHortic.2002.594.42

Rouphael Y, Lucini L, Miras-Moreno B et al (2020) Metabolomic Responses of Maize Shoots and Roots Elicited by Combinatorial Seed Treatments With Microbial and Non-microbial Biostimulants [Original Research]. 11 (664). https://doi.org/10.3389/fmicb.2020.00664

Sharma SS, Dietz K-J (2006) The significance of amino acids and amino acid-derived molecules in plant responses and adaptation to heavy metal stress. J Exp Bot 57: 711-726

Tanou G, Ziogas V, Molassiotis A (2017) Foliar nutrition, biostimulants and prime-like dynamics in fruit tree physiology: new insights on an old topic. Front Plant Sci 8: 1-9. doi:10.3389/fpls.2017.00001

Taylor AG, Grabe DF, Paine DH (1997) Moisture content and water activity of pelleted and film-coated seeds. Seed Sci Technol 19: 24-32

Van-Oosten MJ, Pepe O, De Pascale S et al (2017) The role of biostimulants and bioeffectors as alleviators of abiotic stress in crop plants. Chem Biol Technol Agric 4, 5 doi:10.1186/s40538-017-0089-5

Vranova V, Rejsek K, Skene K, Formanek P (2011) Non-protein amino acids: plant, soil and ecosystem interactions. Plant Soil 342: 31-48.

Wilson HT, Amirkhani M, Taylor AG (2018) Evaluation of Gelatin as a Biostimulant Seed Treatment to Improve Plant Performance. Front Plant Sci, 9. https://doi.org/ARTN 100610.3389/fpls.2018.01006 
Xu CP, Mou BQ (2017) Drench Application of Fish-derived Protein Hydrolysates Affects Lettuce Growth, Chlorophyll Content, and Gas Exchange. Hort Technology 27 (4): 539-543.

https://doi.org/10.21273/Horttech03723-17

Zandonadi DB, Canellas LP, Façanha R (2007) Indolacetic and humic acids induce lateral root development through a concerted plasmalema and tonoplast $\mathrm{H}^{+}$pumps activation. Planta 225: 15831595

\section{Tables}

Table 1 Amino acid, total nitrogen and protein content $(\%)$ and size $(\mathrm{kDa})$ of Hydrolyzed Wheat Gluten (HWG) and Potato Protein (PP)

\begin{tabular}{|c|c|c|c|}
\hline $\begin{array}{l}\text { Protein-based } \\
\text { biostimulants }\end{array}$ & Company & Chemical composition & Remarks \\
\hline \multirow{2}{*}{$\begin{array}{l}\text { Hydrolyzed } \\
\text { wheat gluten } \\
\text { (HWG) }\end{array}$} & \multirow{2}{*}{$\begin{array}{l}\text { A. } \\
\text { Constantino } \\
\text { \& Co. S.P.A., } \\
\text { Italy }\end{array}$} & Amino N\% (w/w)- 3.7 & \multirow[t]{2}{*}{ https://acostantino.com/ } \\
\hline & & Total N \% (w/w)- 13.1 & \\
\hline \multirow{5}{*}{$\begin{array}{l}\text { Potato } \\
\text { protein (PP) }\end{array}$} & \multirow{5}{*}{$\begin{array}{l}\text { Lyckeby, } \\
\text { Sweden }\end{array}$} & Patatin \%- 40 & $40-43 \mathrm{kDa}$ \\
\hline & & Protease inhibitors $\%-50$ & $8-25 \mathrm{kDa}$ \\
\hline & & Other high mol. Wt. protein\%- 10 & $80 \mathrm{kDa}$ \\
\hline & & $\begin{array}{l}\text { Rich in essential amino acids e.g. } \\
\text { aspartic acid, glutamic acid, leucine, } \\
\text { lysine etc. but low in Sulphur } \\
\text { containing amino acid. }\end{array}$ & \\
\hline & & (Muneer, 2015) & \\
\hline
\end{tabular}

Table 2 Description of factors of the experiment 


\begin{tabular}{|c|c|c|}
\hline Factors & Levels & Remarks \\
\hline Variety & I, II and III & \\
\hline \multirow[t]{3}{*}{ Biostimulant } & $\begin{array}{l}\text { Hydrolyzed wheat } \\
\text { gluten }\end{array}$ & HWG \\
\hline & Potato protein film & PF \\
\hline & Potato protein powder & PP \\
\hline $\begin{array}{l}\text { Concentration ( } \mathrm{g} / \mathrm{kg} \\
\text { soil) }\end{array}$ & $0,1,2,5,10$ & \\
\hline \multirow[t]{2}{*}{ Placement } & Bottom-dressing & $\begin{array}{l}\text { Biostimulant is placed } 2 \mathrm{~cm} \text { below seed in the } \\
\text { soil }\end{array}$ \\
\hline & Soil mix & Biostimulant is well mixed with the soil \\
\hline
\end{tabular}

Table 3 Mean squares from analysis of variance (ANOVA) showing effects of variety (Var), type of biostimulant (Type), amount of biostimulant (Amount) and placement of biostimulant (Place) and their two-way interactions on days of emergence, plant height, plant canopy area and total biomass.

\begin{tabular}{|c|c|c|c|c|c|}
\hline \multirow[t]{2}{*}{ Source } & \multirow[t]{2}{*}{ DF } & \multicolumn{4}{|l|}{ Mean square } \\
\hline & & Days-to-emergence & Plant height & Plant canopy area & Total biomass \\
\hline Var & 2 & $116.679 \star \star \star$ & $113.417^{\star \star \star}$ & 6.379 & $18.86^{* *}$ \\
\hline Type & 2 & $170.751^{\star \star \star}$ & $85.56^{\star \star \star}$ & $22.036^{\star \star}$ & 0.86 \\
\hline Amount & 4 & $266.185^{\star \star \star}$ & $797.581^{\star \star \star}$ & $287.271^{\star \star \star}$ & $83.55^{\star \star \star}$ \\
\hline Place & 1 & 0.002 & 23.587 & 15.394 & \\
\hline Rep & 4 & 11.324 & 10.802 & 4.385 & \\
\hline Var*Type & 4 & 4.02 & 8.174 & 9.185 & 4.08 \\
\hline Var*Place & 2 & 161.234 & 1.149 & 5.77 & \\
\hline Type*Amount & 8 & $83.798 * \star \star$ & $30.539 * \star \star$ & $12.664^{\star \star}$ & $10.24 *$ \\
\hline Error & 370 & 15.497 & 8.718 & 4.565 & 3.69 \\
\hline
\end{tabular}

DF- degree of freedom, $*: p<0.05, * *: p<0.01, * * *: p<0.001$

Table 4 Mean values of days-to-emergence, plant height, plant canopy area and total biomass dependent on variety, as well as type and amount of biostimulant. 


\begin{tabular}{|lllll|}
\hline Source & $\begin{array}{l}\text { Days-to- } \\
\text { emergence }\end{array}$ & $\begin{array}{l}\text { Plant height } \\
(\mathrm{cm})\end{array}$ & $\begin{array}{l}\text { Plant canopy area (\% } \\
\text { pixel) }\end{array}$ & $\begin{array}{l}\text { Total } \\
\text { biomass } \\
\text { (g/plant) }\end{array}$ \\
\hline Variety & $17 \mathrm{~b}$ & $12.1 \mathrm{a}$ & $5.25 \mathrm{a}$ & $5.45 \mathrm{~b}$ \\
\hline I & $17 \mathrm{~b}$ & $10.4 \mathrm{~b}$ & $4.90 \mathrm{a}$ & $5.14 \mathrm{~b}$ \\
\hline II & $19 \mathrm{a}$ & $11.3 \mathrm{ab}$ & $5.34 \mathrm{a}$ & $6.87 \mathrm{a}$ \\
\hline III & & & & $6.25 \mathrm{a}$ \\
\hline Type of biostimulant & $19 \mathrm{a}$ & $10.6 \mathrm{~b}$ & $5.06 \mathrm{ab}$ & $6.12 \mathrm{a}$ \\
\hline HWG & $17 \mathrm{~b}$ & $12.1 \mathrm{a}$ & $5.61 \mathrm{a}$ & $5.88 \mathrm{a}$ \\
\hline PF & $17 \mathrm{~b}$ & $11.2 \mathrm{~b}$ & $4.82 \mathrm{~b}$ & \\
\hline PP & & & $2.68 \mathrm{~d}$ \\
\hline $\begin{array}{l}\text { Amount of biostimulant } \\
\text { (g/kg soil) }\end{array}$ & & & & $7.16 \mathrm{~b}$ \\
\hline 0 & $15 \mathrm{~d}$ & $7.1 \mathrm{c}$ & $2.60 \mathrm{c}$ & $8.63 \mathrm{a}$ \\
\hline 1 & $16 \mathrm{~cd}$ & $14.3 \mathrm{a}$ & $6.83 \mathrm{a}$ & $4.55 \mathrm{c}$ \\
\hline 2 & $17 \mathrm{~b}$ & $14.3 \mathrm{a}$ & $7.10 \mathrm{a}$ & $3.99 \mathrm{c}$ \\
\hline 5 & $19 \mathrm{ab}$ & $10.9 \mathrm{~b}$ & $4.90 \mathrm{~b}$ & \\
\hline 10 & $20 \mathrm{a}$ & $9.8 \mathrm{~b}$ & $4.38 \mathrm{~b}$ & \\
\hline
\end{tabular}

Numbers followed by the same letter within a column for a source do not differ significantly

Table 5 Examples of protein-based biostimulants and their effects on biomass of different crops. Rows with one value indicated that authors only reported total biomass. 


\begin{tabular}{|c|c|c|c|c|}
\hline Authors & Crops & Protein-based biostimulant products & $\begin{array}{l}\% \text { shoot } \\
\text { increase }\end{array}$ & $\begin{array}{l}\% \text { root } \\
\text { increase }\end{array}$ \\
\hline $\begin{array}{l}\text { Al-Malieky and } \\
\text { Jerry, } 2019\end{array}$ & Lettuce & Fish by-product & 67.3 & \\
\hline $\begin{array}{l}\text { Amirkhani et al. } \\
2016\end{array}$ & Broccoli & Soy-protein-based biostimulant & 35.9 & \\
\hline $\begin{array}{l}\text { Baglieri et al. } \\
2014\end{array}$ & Beans & Tomato-hydrolysates & 87.4 & 86.1 \\
\hline \multirow{2}{*}{$\begin{array}{l}\text { Cardarelli et al. } \\
2020\end{array}$} & Lettuce & \multirow[t]{2}{*}{ Legume-derived biostimulant } & 28.6 & 20.0 \\
\hline & Tomato & & 41.2 & 40.0 \\
\hline $\begin{array}{l}\text { Caruso et al. } \\
2019\end{array}$ & $\begin{array}{l}\text { Perennial } \\
\text { wall rocket }\end{array}$ & $\begin{array}{l}\text { Trainer (Legume-derived } \\
\text { biostimulant) }\end{array}$ & 17.2 & \\
\hline Colla et al. 2014 & Tomato & $\begin{array}{l}\text { Trainer (Legume-derived } \\
\text { biostimulant) }\end{array}$ & 21.0 & 35.0 \\
\hline $\begin{array}{l}\text { Cristiano et al. } \\
2018\end{array}$ & Snapdragon & $\begin{array}{l}\text { Hydrostim (Animal-derived protein } \\
\text { hydrolysates) }\end{array}$ & 13.0 & 10.0 \\
\hline Ertani et al. 2013 & Maize & Alfalfa-protein hydrolysates & 18.9 & 77.3 \\
\hline Ertani et al. 2017 & Tomato & Alfalfa-protein hydrolysates & 26.0 & 21.4 \\
\hline \multirow[t]{2}{*}{ Ertani et al. 2019} & \multirow[t]{2}{*}{ Maize } & \multirow{2}{*}{$\begin{array}{l}\text { Chicken pea (Spirulina platensis) } \\
\text { protein hydrolysates }\end{array}$} & 75.0 & 58.0 \\
\hline & & & 29.0 & 17.0 \\
\hline $\begin{array}{l}\text { Genc and Atici, } \\
2019\end{array}$ & Wheat & Chicken feather protein & 21.7 & \\
\hline $\begin{array}{l}\text { Gurav and } \\
\text { Jadhav } 2013\end{array}$ & Banana & Degraded chicken feather protein & 18.7 & \\
\hline Lucini et al. 2015 & Lettuce & $\begin{array}{l}\text { PH Trainer (Legume-derived } \\
\text { biostimulant) }\end{array}$ & 18.2 & 66.7 \\
\hline $\begin{array}{l}\text { Rouphael et al. } \\
2020\end{array}$ & Maize & $\begin{array}{l}\text { Coveron (Legume-derived protein } \\
\text { hydrolysates) }\end{array}$ & 17.9 & 22.8 \\
\hline $\begin{array}{l}\text { Xu and Mou, } \\
2017\end{array}$ & Lettuce & Fish protein hydrolysates & 40.0 & 53.8 \\
\hline Our results & Sugar beet & HWG and PP & 194.6 & 66 \\
\hline
\end{tabular}



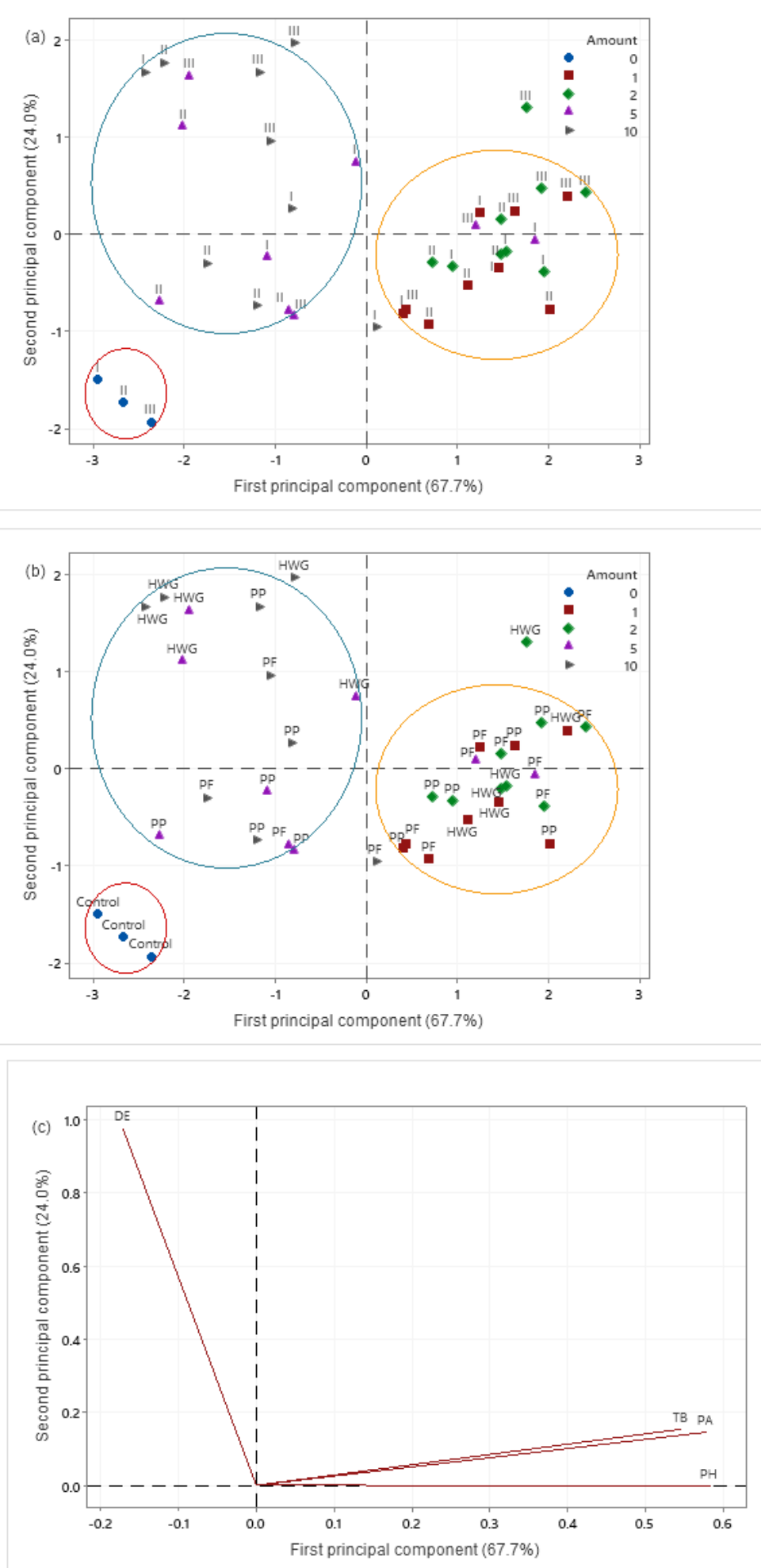

\section{Figure 1}

Score plots sorted by variety (a) and by types of biostimulants (b) and loading plot (c) obtained from principal component analysis of growth parameters (days-to-emergence - DE, plant height - PH, plant canopy area - PA, and total biomass - TB) of sugar beet under protein-based biostimulant treatment 


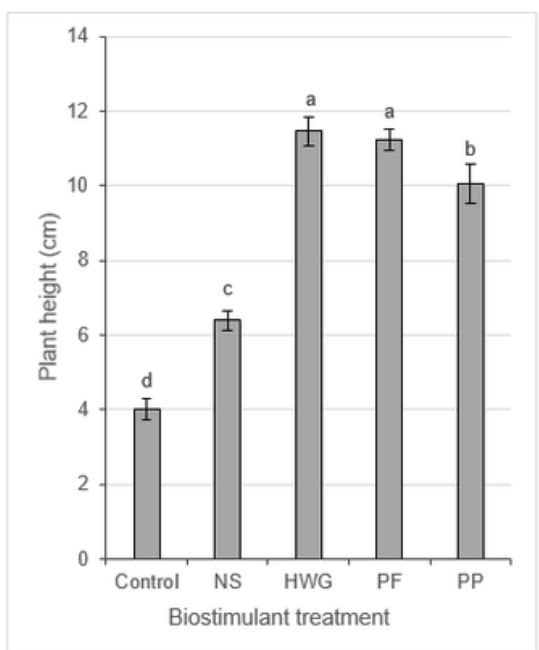

A

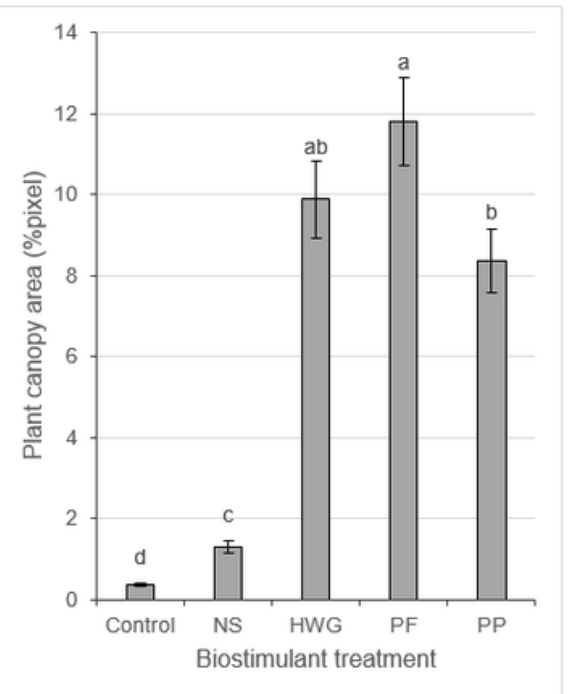

B

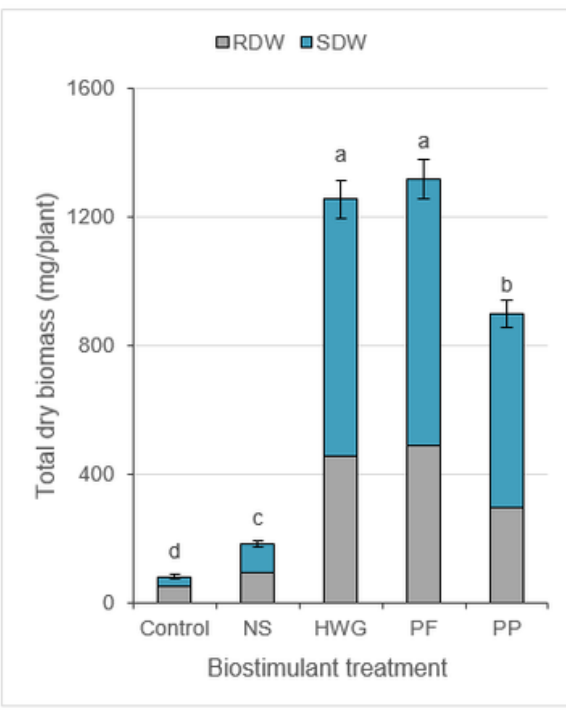

C

Figure 2

Growth parameters (plant height (a), plant canopy area (b) and total dry biomass of root (RDW) and shoot (SDW) (c) of sugar beet under protein-based biostimulant treatments (HWG, PF and PP) in comparison with nutrient solution (NS), 8 weeks after planting. Each bar is a mean of four replicates $(n=4)$ and bars are separated using standard error. Bars sharing similar alphabet are not significantly different from each other 